\title{
Penelitian tentang Persyaratan dan Kekhususan Kalimat Pasif dalam Bahasa Jepang dan Perbandingannya dalam Bahasa Indonesia
}

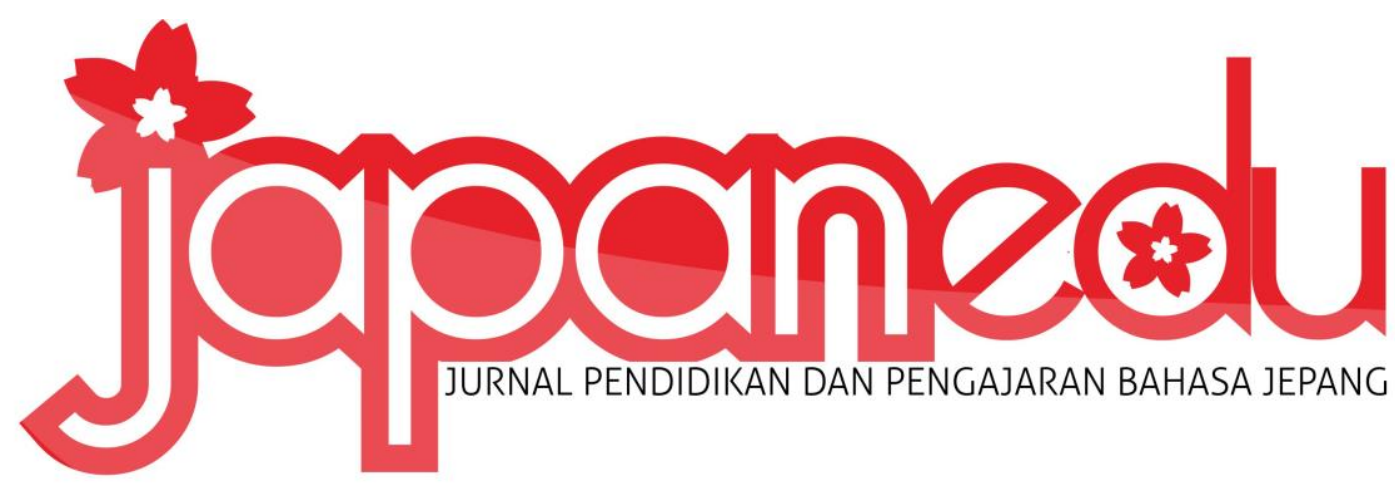

Andi Irma Sarjani

andiirma2210@gmail.com

Jurusan Bahasa Jepang

Fakultas Sastra

Universitas Darma Persada

\begin{abstract}
Abstrak. Dalam kalimat pasif bahasa Jepang, dikenal kalimat pasif langsung yang memiliki padanan dengan kalimat aktif, dan kalimat pasif tidak langsung yang tidak memiliki padanannya dalam kalimat aktif. Kalimat pasif langsung dalam bahasa Indonesia diekspresikan dengan imbuhan "di-", tetapi pada kalimat pasif tidak langsung tidak dapat diekspresikan dengan imbuhan "di-", Ditambah lagi, berdasarkan hasil angket terhadap pembelajar bahasa Jepang, dimana ditanyakan mengenai adakah bentuk pasif dari kalimat aktif「私は木村君を褒めた」dan apakah itu alami atau tidak, semua responden menjawab bahwa bentuk pasifnya ada dan alami yaitu「木村君は私に褒められた」, yang dalam bahasa Indonesia adalah, "Kimura dipuji oleh saya". Dalam bahasa Indonesia, kalimat pasif seperti contoh di atas bisa diterima, tetapi dalam bahasa Jepang kalimat pasif tersebut sangat tidak alami. Menurut Takami (2011), ada 4 syarat yang penting dalam kalimat pasif langsung bahasa Jepang, yaitu sudut pandang pembicara, syarat perubahan kondisi, syarat adanya kekhususan dan syarat adanya kerugian. Dalam bahasa Jepang, apabila dari 4 syarat tersebut terpenuhi salah satunya (atau dua syarat atau lebih), maka kalimat pasif tersebut dapat diterima. Bila melihat ke dalam kalimat pasif dalam bahasa Indonesia, tidak ada 4 syarat seperti terdapat dalam kalimat pasif bahasa Jepang. Dan ada kecenderungan bahwa semua kalimat pasif dalam bahasa Jepang akan diterjemahkan dengan memakai imbuhan "di-". Begitu pula sebaliknya, semua kata berimbuhan "di-"akan diterjemahkan kedalam bentuk pasif dalam bahasa Jepang. Terutama, seperti pada kalimat "sayuran segar dicuci dahulu sebelum dimakan", sangat tidak alami apabila diterjemahkan kedalam bentuk pasif dalam bahasa Jepang. Menurut Sneddon (1996), ada dua jenis kalimat pasif dalam bahasa Indonesia. Yang pertama adalah kalimat pasif tipe 1 dan kalimat pasif tipe 2. Penderita pada kalimat pasif tipe 1 adalah
\end{abstract}


kata ganti orang ke-3, dimana objek pada kalimat aktif berubah menjadi subjek pada kalimat pasif, dan imbuhan "me-" berubah menjadi imbuhan "di-". Kalimat pasif tipe 2, pelaku merupakan kata ganti orang. Pada tipe ini, objek pada kalimat aktif dipindahkan ke awal kalimat, dan kalimat pasif dibentuk dengan cara menghapus imbuhan "me-" pada kata kerja. Bentuk ini juga disebut "pasif zero". Adanya syarat dan kekhususan kalimat pasif dalam bahasa Jepang serta bentuk-bentuk pasif dalam bahasa Indonesia yang tidak semuanya bisa berbentuk pasif dalam bahasa Jepang inilah yang belum dipahami oleh pembelajar Indonesia sehingga menyebabkan sulitnya memahami kalimat pasif dalam bahasa Jepang.

要旨。日本語の受身文には、よく知られているように、構造上、対応する能動文が存在する 「直接受身文」と、対応する能動文が存在しない「間接受身文」がある。直接受身はインドネ シア語の受身文では、接頭辞の”di-"で表しているが、間接受身は接頭辞の[di]で表すことが出来 ないので、インドネシア人日本語学習者にとって難しいようである。さらに、能動文の「私は 木村君を褒めた」に対して、受身文はどうなるのか、という質問を学生に聞いた結果、「木村 君は私に褒められた」という答えで、インドネシア語の受身文では、[Saya dipuji oleh Kimura]に なったのである。インドネシア語ではその受身文は自然に聞こえているそうだが、日本語では 不適格ことが分かってきた。日本語の受身について、高見（2011）は、直接受身文について、 日本語の受身文には四つの重要な条件がある。その四つの条件／制約のどれか（あるいは二つ 以上）を満たす場合に適格になる。日本語の直接受身に重要な制約・条件が四つ存在するのに 対し、インドネシア語の受身文には日本語のような制約・条件があるだろうか。スネードン （1996）によると、インドネシア語の受身文は二種類がある。それは 1 タイプの受身文や 2 タ イプの受身文である。1タイプの受身文は、行為者は第三者の人か名詞句である。行為者が表 さない場合もこの1タイプの受身文の種類である。これは、インドネシア語の受身文の一般的 なパターンで、能動文に対応する受身文である。1タイプの受身文には構造的に能動文の目的 語が、受身文では主語に置き換えられ、述語にある「me-」接頭辞を「diー」接頭辞に変えて作 られる。実際は、インドネシア人日本語学習者は、このタイプしか理解していないので、日本 語の受身文を接頭辞「di」に訳してしまう傾向がある。逆に、インドネシアごの接頭辞”di”ある 文は、すべて日本語の受身文になってしまう。また、インドネシア語の受身文には、日本語の ような条件·制約が存在しないので、これらのことが日本語の受身文はインドネシア人日本語学 習者にとって分かりにくいと思われる。

\section{1.はじめに}

日本語の受身文には、よく知られているように、構造上、対応する能動文が存在する「直接 受身文」と、対応する能動文が存在しない「間接受身文」がある。直接受身はインドネシア語 の受身文では、接頭辞の “di-”で表しているが、間接受身は接頭辞の“di-”で表すことが出 来ないので、インドネシア人日本語学習者にとって難しいようである。さらに、能動文の「私 は木村君を褒めた」に対して、受身文はどうなのか、そして自然なのか、という質問を学生に した結果、「木村君は私に褒められた」で自然であると答えた。インドネシア語の受身文では、 “Kimura dipuji oleh saya.”になる。インドネシア語ではこの受身文は自然なようだが、日 本語では不適格である。インドネシア語の「Kimura saya puji」は自然な受身文で、日本語の 受身文「木村君は私に褒められた」は何故不自然なのか。それは、受身の本質についての基本 的な違いがあるからと思われる。では、日本語の受身文とインドネシア語の受身文ではどんな 
相違点や共通点があるのか、考えてみよう。これらの点はネイティブスピーカーである日本人 にとっては、ある意味で自明なことなのだろうが、インドネシア人日本語学習者にとっては学 習、使用上の大きな困難となってしまう。

\section{2. 日本語の受身}

まず、日本語の受身に関する条件や特徵については次のようになる。日本語の受身について、 高見（2011）は、次のように述べている。まず、直接受身文について、日本語の受身文には四 つの重要な条件がある。

\section{1. 受身文の話し手の視点規則}

高見 $(2011: 15,28)$ によると、「話し手の視点規則」というのは、話し手（や書き手）は一 般に、自分に近い、親しみのある人や物寄りに自分の視点を置き、それを文の主語（または主

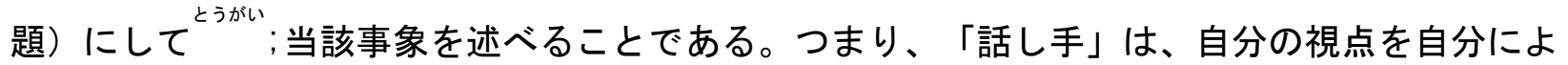
り近い、親しみのある特定の人物に近づけないで、親しみのより ; 薄いと考えられる無生物に 自分の視点を近づけることが一般に難しい。

日本語の受身文は、話し手がある事象の動作主（行為者）ではなく、その動作・行為を受け る対象（つまり、受身文の主語）に自分の視点を寄せてその事象を述べる文である。次のよう な能動文と受身文を考えてみよう。

例：(1)

褒める

$$
\text { 私 }
$$

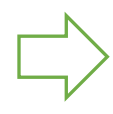

木村君

（2）a. 私は木村君を褒めた。

b. **木村君は私に褒められた。（高見 2011：20）

（1）では、話し手自身が木村君を褒めており、これは（2a）のように能動文で言うのが普通で ある。（2b）のように受身文にすると、話し手が自分を客観視し、他人のように扱っている感 じがして、極めて不自然である。この点は「話し手の視点規則」で説明できる。話し手は当然、 他人より自分のほうが自分により近く、「親しみ」があるため、自分寄りの視点をとるのが最 も自然である。そのため、（2a）の能動文を用いるのが一般的であり、わざわざ他人の木村君 寄りの視点をとっている（2b）の受身文は、「視点規則」に違反して不適格となる。

これに対し、例えば、ある人がある人を「褒める」ような場合は、どのように表現されるだ ろうか。山田先生が木村君を褒めたというような場合を考えてみよう。

（3）動作主褒める 対象

山田先生

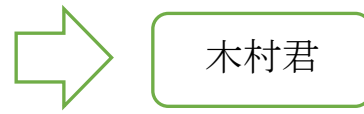




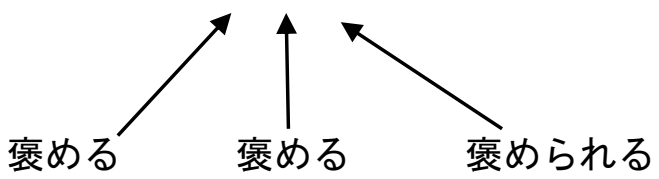

（4）a. 山田先生は木村君を褒めた。（能動文）

b. 木村君は山田先生に褒められた。（受身文）（高見 2011：17）

（3）の図で、山田先生が木村君を襄める場合、山田先生は木村君に一方的に働きかけ、木村君 自身は何もしない。この一方向の働きかけを片方向の上の矢印で示そう。さてここで、話し手 が山田先生寄りの視点か、中立の視点をとって（3）の事象を述べれば、（4a）のように能動文 で表現するが、話し手が木村君寄りの視点をとれば、受身形が用いられる、つまり、（4b）の 受身文「木村君は山田先生に襄められた」が用いられることになる。したがって受身文は、話 し手がある事象の動作主（行為者）ではなく、その動作・行為を受ける対象（つまり受身文の 主語）に自分の視点を寄せてその事象を述べる文であることが分かる。そして、（4a）の能動 文は、主語（主題）の「山田先生」について述べた文であり、（4b）の受身文は、同じく主語 (主題) の「木村君」について述べた文である。

\section{2. 受身文の状態変化制約}

高見（2011：24）によると、日本語の受身文は、動詞が表す事象が、その主語指示物を直接 対象としてなされ、その状態に変化や影響を及ぼす場合に適格となる。

例 :

（5）a. 僕の友達は山田先生に吨られた。

b. 遭難者は暴風雨の中、幸いにも救助隊に助けられた。

c. 多くの家が台風で壊された。（高見 $2011: 21 ）$

（6）a. *花子は太郎に駅前で 5 分待たれた。

b. * *山田先生は村山先生に会場で偶然見かけられた。

c. *太郎は花子に知られている。（高見 2011：21）

（5）、（6）の動詞「叱る、助ける、壊す、待つ、見かける、知る」は、いずれも目的語を必 要とする他動詞であり、これらの受身文は、話し手がその目的語に自分の視点を寄せて、それ を主語にした受身文である。しかし、（5a-c）は日本語としてまったく自然であるが、（6a-c） は日本語として容認されない不適格である。（5a）では、山田先生が話し手の友達を直接対象( direct target) として吨るという行為を行い、その友達はその行為の結果、変化や影響を受け ることになる。（5b) も同様で、救助隊が遭難者を助けたことにより、遭難者は救助されて、 それまでの状態から変化を受けている。また、（5c）でも、家が普通の状態から壊されて変化 を受けている。これに対し、（6a）では、太郎が花子を待つという行為は、太郎一人が勝手に 行う自律的行為であり、花子には何もされていない。そのため、花子はそのことで何の変化も 受けていない。同じように（6b）で、村山先生が山田先生を偶然見かけるという行為は、山田 先生に対しては何もなされておらず、山田先生はそのことで何の変化も受けていない。さらに

(6c) で、花子が太郎のことをよく知っていても、太郎に何かがなされているわけではなく、 
太郎はそのことで変化を受けていない。つまり、適格な（5a-c）では、不適格な $(6 \mathrm{a}-\mathrm{c})$ と違っ て、受身文の主語指示物を直接対象として何かがなされ、主語指示物はそのことにより、それ 以前の状態から变化し、影響を受けていることが分かる。

\section{3. 受身文の特徵付け制約}

高見（2011：31）によると、日本語の受身文には、その主語の状態変化を述べるという意味 機能だけでなく、その主語がどのような特徵、特性、属性を持っているかを述べる意味機能も ある。

例：（7）a. *この山は昨日、太郎に登られた。

b. この山は、もう数百年も前に山頭火に登られている。（高見 2011：31）

（8） a. *このプールは昨日、小学生に泳がれた。

b. このプールはまだ誰にも漽がれていない、完成したばかりのプールです。

（「日本語基本動詞用法辞典」pp. 406-407）

（9）富士山は日本一高い山として、世界の人々に知られている。

(10) モーツァルトの曲は、 ろうにゃくなんによ

; 老若男女を問わず、全世界の多くの人々 に愛されている。

(高見 $2011: 34)$

（7ab）の文はともに主語が「この山」というく無生物＞であるため、両方とも視点規則に違反 している。また、人が山に登っても、その山が変化や影響を受けているとは考えられないため、 これらの文は受身状態変化制約にも違反している。そのため、（7a）が不適格なのは理解でき る。ところが (7b) では、山頭火が数百年も前にその山に登っているというような特徴付け、 性格付けがなされているので、適格となる。また、（8a）では、小学生が昨日そのプールで泳 いだとしても、そのことによってそのプールの特徴や属性は何も述べられていない。一方（8b） では、そのプールが完成したばかりで、まだ誰も泳いでいないということによって、そのプー ルができたばかりの真新しいプールであるという特徴づけがある。同じように、（9）、 は、富士山がどんな山か、モーツァルトの曲はどんな曲かを述べており、それらの性格付けを 行っている。よって、これらの受身文は特徵付け制約を満たして適格となる。つまり、日本語 の受身文は話し手がその主語を特徵/性格付けるときに適格となることが分かる。

\section{4. 受身文の利害表現制約}

高見（2011：34）によると、日本語の受身文の意味機能には、主語の状態変化や特徴を述べ るだけでなく、もうーつ、利害の表明という意味機能がある。

例：（11）a. *学校の廊下が猫に歩かれた。

b. ワックス塗り立ての学校の廊下が猫に歩かれ、足跡が残ってしまった。

（12）a. *信州大学は山田君に入学された。

b. 信州大学はオウム真理教徒に入学された。（高見 2011：35）

（11a）、（12a）で、猫が学校の廊下を歩いたり、山田君が大学に入学しても、そのことによ って廊下や大学が変化や影響を受けるとは考えられない。そのため、これらの文は受身文の状 
態変化制約を満たしていない。さらにこれらの受身文は、主語が無生物で、「ニ」格名詞句が 特定の人間（や動物）であるため、話し手の視点規則にも違反している。さらに、受身文の主 語が当該事象により特徵付けられていない。以上の理由により、これらの文は不適格になると 考えられる。しかし (11b) では、猫がワックス塗り立ての廊下を歩いたことで話し手が被害・ 迷惑を被っていることが示されている。（12b）も同様で、オウム真理教徒が大学に入学してき たことで、大学関係者が迷惑を被っていることが示されている。これらの文を見ると、受身文 は、主語の状態変化や特徴を述べていなくても、あるいは話し手の視点規則に違反していても、 話し手や主語がその受身文の表す事象により、被害や迷惑を被っていることが示されれば適格 になることが分かる。

以上のことから、日本語の受身文は、次の四つの条件／制約のどれか（あるいは二つ以上） を満たす場合に適格になる。（高見 2011：16, 44）

1. 受身文の話し手の視点規則

話し手（や書き手）は一般に、自分に近い、親しみのある人や物寄りに自分の視点を 置き、それを文の主語（または主題）にして当該事象を述べる。

2. 受身文の状態変化制約

受身文は、動詞が表す事象が、その主語指示物を直接対象としてなされ、その状態に 変化や影響を及ぼす場合に適格となる。

3. 受身文の特徵付け制約

受身文は、話し手がその主語を特徵/性格付けるときに適格となる。

4. 受身文の利害表明制約

受身文は利害の意味を伝達するときに適格となる。

3.インドネシア語の受身文

3．1．インドネシア語の受身の作り方

スネドン（1996）によると、インドネシア語の受身文は二種類ある。それは 1 タイプの受身 文と 2 タイプの受身文である。1タイプの受身文は、行為者は 3 人称である。能動文の目的語 が受身文では主語に置き換えられ、動詞の接頭辞“me-”を接頭辞“di-”に变えて作られる。

例えば、

能動文 Dia menjemput saya.

主語 me-動詞 目的語

受身文 Saya di jemput oleh dia (=Saya di jemputnya) 主語 di-動詞行為者 
一方、2タイプの受身文は、受身の動作主（agent）は代名詞である。このタイプは目的語を文 頭に移動させ、動詞の「me-」接頭辞を消すことで受身文になり、ゼロタイプとも呼ばれてい る。

例えば、

能動文 Kami menjemput dia.

受身文 Dia kami jemput.

\section{3．2．インドネシア語の受身に四つの制約はあるか}

2 で述べたように、日本語の直接受身に重要な制約・条件が四つ存在するのに対し、インド ネシア語の受身文には日本語のような制約・条件があるだろうか。まず、上記の日本語の受身 文の例をインドネシア語に訳してみよう。

（13）a. 私は木村君を褒めた。 Saya memuji Kimura.

b. *木村君は私に襄められた。 Kimura saya puji.

（13a）では、日本語と同様に、話し手自身が木村君を褒めている。そして（13b）のように 受身文にすると、日本語では極めて不自然である。上で述べたように、「話し手の視点規則」 により、話し手は当然、自分寄りの視点をとるのが最も自然であるが、この文は自分ではなく 木村君の視点をとっているためである。しかし、インドネシア語では、（13b）の受身文はまっ たく自然であり、「木村」という自分以外の人を主語にしても適格である。日本語学科の学生 を対象にアンケートを行った結果も、皆「木村君は私に褒められた」という受身文は正しいし、 自然だと答えられた。つまり、インドネシア語の受身文には、日本語のような「話し手の視点 規則」が存在せず、自分に近い、または親しみのある人や物を文の主語（または主題）にしな くても、インドネシア語の受身として適切であることが分かる。すなわち、この違いがインド ネシア人日本語学習者にとっては大きな問題となっており、日本語の受身文の注意すべきポイ ントだと思われる。 次に状態変化制約の例文を見てみよう。

（14）a. 僕の友達は山田先生に吨られた。 Teman saya dimarahi (oleh) Pak Yamada.

b. 遭難者は暴風雨の中、幸いにも救助隊に助けられた。 Dalam keadaan angin badai, korban diselamatkan oleh pasukan militer.

c. 多くの家が台風で壊された。（高見 $2011: 21 ）$

Banyak rumah dirusak oleh angin topan.

（15）a. *花子は太郎に駅前で 5 分待たれた。 Hanako ditunggu Taro di depan stasiun selama 5 menit.

b. *山田先生は村山先生に会場で偶然見かけられた。

Pak Yamada secara tidak sengaja dilihat oleh Pak Murayama di tempat pertemuan. c. **郎は花子に知られている。 
Taro dikenal oleh Hanako.

以前述べたように、日本語では上の例文は受身文として不適格である。それは、日本語の受 身文には状態変化制約が存在するからである。一方、インドネシア語の (14a, b, c ) や (15a, b, c) は、どれも受身として自然であり、日常会話でもよく使われている。したがって、イ ンドネシア語の受身文には状態変化制約が存在しないことが分かる。

次の特徴付け制約の例文を考えてみよう。

（16）a.＊この山は昨日、太郎に登られた。 Gunung ini kemarin didaki oleh Taro.

b. この山は、もう数百年も前に山頭火に登られている。（高見 $2011: 31 ）$ Gunung ini didaki oleh Santouka lebih dari ratusan tahun yang lalu.

(17) a. *このプールは昨日、小学生に泳がれた。 Kolam ini kemarin direnangi oleh anak SD.

b. このプールはまだ誰にも泳がれていない、完成したばかりのプールです。 Kolam ini belum direnangi oleh siapapun, karena kolam ini baru saja selesai.

（「日本語基本動詞用法辞典」pp. 406-407）

（18）富士山は日本一高い山として、世界の人々に知られている。 Gunung Fuji sebagai gunung tertinggi di Jepang, dikenal oleh orang-orang dari seluruh dunia.

（19）モーツァルトの曲は、老若男女を問わず、全世界の多くの人々に愛されている。 Lagu Mozart tidak hanya oleh anak-anak muda, tapi dicintai oleh banyak orang di seluruh dunia.

(高見 $2011: 34)$

前に述べたように、日本語では（16）（17）の例文は受身文として不適格である。それは、 日本語の受身文は特徵付け制約が存在するからである。一方、インドネシア語では（16a, b) は、 いずれも受身として自然であり、適格である。また（18）（19）は日本語では適格だが、イン ドネシア語でも適格である。したがって、インドネシア語の受身文は変化や影響だけでなく、 特徵付けも必要とされていないことが分かる。

次は、受身文の利害表明制約について考えてみよう。上で述べたように、日本語の受身文は 利害表明制約が存在するのに対して、インドネシア語はどうなるだろうか。次の例文を考えて みよう。

（20）a. *学校の廊下が猫に歩かれた。 Lorong sekolah dilewati kucing.

b. ワックス塗り立ての学校の廊下が猫に歩かれ、足跡が残ってしまった。 Lorong sekolah yang baru saja dicat dilewati kucing, sehingga berbekas tapak kakinya.

（21）a.*信州大学は山田君に入学された。 Universitas Shinshuu dimasuki oleh Yamada.

b. 信州大学はオウム真理教徒に入学された。（高見 2011：35） Universitas Shinshuu dimasuki oleh mahasiswa penganut kepercayaan Oum. 
前に述ベたように、日本語の（20a）（21a）は不適格だが、(20b) (21b)は適格である。それは 利害表明制約が存在するからである。一方、インドネシア語では、上の $(20 a, b)$ や $(21 a, b)$ は すべて受身文として普通である。したがって、利害・迷惑が表示しなくても受身文として適格 となることが分かる。

以上のことから、日本語とインドネシア語の受身の異なる点が明らかになった。

3. 3.インドネシア語の受身の特徵（制約）

インドネシア語には、日本語のような条件·制約がまったくないが、インドネシア語では、ー 般的には、次のような場面で受身文が使われることが多い。例えば、次の例を見てみよう。

(22) Sepedanya dicuri tadi malam.

彼の自転車は昨夜盗まれた。

(23) Saya disuruh pergi.

私は行くように命令された。

(Sneddon1996: 262)

上の $(22,23)$ の例文を見ると、インドネシア語では、動作を行った人が分からない時、または 動作を行った人物が誰でもいいとき、受身文で表す。（22）の例文「彼の自転車は昨夜盗まれ た」では、自転車は人に盗まれたことは事実であるが、誰がその動作を行ったかまったく分か らず、誰でも可能性がある。結果として、自転車が無くなった。

また、（23）の「私は行かされた」の場合も、誰がその動作を行ったか不明である。これらの 例文から、動作が行われる対象を強調したい場合、受身で表すことが分かる。

まとめると,インドネシア語の受身文には次のような場合に用いられることが分かる。

1. 動作を行った人が分からない時。

2. 動作が行われる対象を強調したい時。

3.その動作を行った人物を特定する必要がない時。

(Sneddon1996:262/Mc.Cune 1979:282-284)

しかし、インドネシア語では IPNS (Indonesian Passive of Narrative Sequence/物語連続受 身) と呼ばれる特別な構文がある。（cf. Bambang 1989）。その例は次のような（24）の例文で ある。

(24) Sebelum dimakan, sayuran dicuci dahulu sampai bersih.

上の例文には、接頭辞” di- “が二つ現れている。すなわち” dimakan” と “dicuci”である。 インドネシア語の文章には接頭辞” $\mathrm{di}$ - “があるので、筆者が行ったアンケートではダルマ・プ ルサダ大学日本語学科、6 学期の 70 人の学生を対象に、80パーセントの学生は受身文として訳 している。インドネシア語の文章には接頭辞” di- “があるので、学生の答えなりに、「食べら れる前に、まず野菜をきれいに洗われます」）。 
次の例文も見てみよう。

(25) Pak Atma ingin mengirimkan uang kepada Ayah. Ia pergi ke kantor pos yang terdekat. Dibelinya sebuah formulir wesel pos lalu di isinya.

（佐々木 2014：156）

上の文章は日本語では「（彼は）用紙を買って、（彼は）必要事項を記入する」という意味で ある。もし受身を用いて「用紙が買われて、必要事項が記入される」とすると不自然である。 インドネシア語では、同じ行為者の文が続くので、接頭辞”di-“が使われている。さらに、イ ンドネシア語では ‘action focus' であるので、接頭辞” di-“を用いると思われる。（24）の 例文も同様に、” dimakan” や“dicuci”も も action focus” なので、接頭辞” di-“を用いる が、日本語では受身文で表さない方が自然である。

4. まとめ

この研究を通して、インドネシア語日本語学習者は、高見が述べた四つの条件·制約を理解す れば御用が起こらないと思われる。さらに、インドネシア語の受身文の制約も理解すれば、誤 用が起こらないことを信じている。また、インドネシアの接頭辞” di- “がある文は必ずしも日 本語の受身文になるわけではないことを日本語学習者に理解してもらいたい。

\section{参考文献}

Bambang Kaswanti Purwo (ed.), Serpih-Serpih Telaah Pasif Bahasa Indonesia, 1989, Penerbit Kanisius.

James Neil Sneddon et.al, Indonesian A Comprehensive Grammar, 2nd edition, 1996, Rout ledge.

Mc. Cune, Keith, Passive Function and The Indonesian Passive, dalam Oceanic Linguistics XVIII (2): 119-169.

佐々木重次、インドネシア語の中庭・文法篇 改版、2014、Grup Sanggar.

高見健一、日本語の受身と使役・その意味規則を探る、2011、開拓社。 